Miller, P. W., A. W. Ellis, and S. J. Keighton, 2015: The utility of total lightning trends in diagnosing single-cell thunderstorm severity: Examples from the central Appalachians region. J. Operational Meteor., 3 (8), 82-98, doi: http://dx.doi.org/10.15191/nwajom.2015.0308.

Journal of Operational Meteorology Article

\title{
The Utility of Total Lightning Trends in Diagnosing Single- cell Thunderstorm Severity: Examples from the Central Appalachians Region
}

\author{
PAUL W. MILLER \\ University of Georgia, Athens, Georgia \\ ANDREW W. ELLIS \\ Virginia Tech, Blacksburg, Virginia \\ STEPHEN J. KEIGHTON \\ NOAA/NWS, Blacksburg, Virginia
}

(Manuscript received 30 September 2014; review completed 17 March 2015)

\begin{abstract}
The performance of a total lightning jump algorithm for guiding severe thunderstorm warnings within a weakly sheared environment was investigated using data from the Earth Networks Total Lightning Network. Total lightning observations from two summers for a study domain within the central Appalachian Mountains region were clustered into likely thunderstorms using single-linkage clustering. The spatial and temporal characteristics of each flash cluster were evaluated and used to assign a "storm index" (SI) score to each cluster. Small, short-lived, slow-moving, circular clusters—consistent with single-cell thunderstormswere given large SI scores, and large, long-lived, fast-moving, linear clusters-inconsistent with the single-cell mode-received smaller SI scores. Statistical testing revealed that days with a simple majority of lightningdefined (LD) single-cell storms possessed significantly weaker 0-6-km wind shear than days with a majority of non-single-cell storms. After classifying 470 clusters as either LD single-cell or multicell/supercell, the $2 \sigma$ lightning jump algorithm was applied to the flashes associated with each cluster. Total lightning jumps identified by the algorithm were aligned with severe weather report data to evaluate the accuracy of the algorithm. Although probability of detection values for both categories compared well to previous studies, false alarm rates were significantly larger than previously documented. The algorithm performed unsatisfactorily among the LD single-cell and multicell/supercell storms studied, and its performance deteriorated further when applied to a subset of storms most clearly defined as single-cell. However, severe LD storms demonstrated greater flash rates, a promising characteristic for future lightning-based warning tools.
\end{abstract}

\section{Introduction}

With the growth of ground-based, very-highfrequency (VHF) lightning locating systems, the "total lightning jump" has emerged as a focal point within the severe weather research arena. Total lightning, which is the sum of intracloud (IC) and cloud-toground (CG) lightning, occurs in much greater quantities than CG lightning alone (e.g., Goodman et al. 1988; MacGorman et al. 1989, 2011; Boccippio et al. 2001) and offers more comprehensive insight into storm electrification. Many studies have documented sharp increases (i.e., a "jump") in the total lightning flash rate of severe thunderstorms prior to the onset of severe weather ${ }^{1}$ at the surface (e.g., Goodman et al. 1988; Williams et al. 1999; Goodman et al. 2005; Schultz et al. 2009, 2011; Darden et al. 2010; Gatlin and Goodman 2010; Rudlosky and Fuelberg 2013).

\footnotetext{
1 The United States National Weather Service defines a severe thunderstorm as one producing at least one of the following: a tornado, hail $\geq 1.0$ in $(2.54 \mathrm{~cm})$ in diameter, or winds $\geq 58 \mathrm{mi} \mathrm{h}^{-1}\left(93.3 \mathrm{~km} \mathrm{~h}^{-1}\right)$.
} 
From the first formulation of a lightning jump algorithm (LJA) by Gatlin (2007) and through the refinements made by Schultz et al. $(2009,2011)$, there have been several definitions for the increase in total flash rate that constitutes a jump. The " $2 \sigma$ algorithm" (Schultz et al. 2009, 2011), so named for its requirement that the current flash rate exceed two standard deviations of the running mean flash rate, has been tentatively adopted by researchers as the standard version of the algorithm (Schultz et al. 2011; Rudlosky and Fuelberg 2013) due to its performance relative to other tested versions of an LJA (Schultz et al. 2009). Recently, attention has shifted from establishing the consistency and reliability of lightning jumps (e.g., Schultz et al. 2009, 2011; Gatlin and Goodman, 2010) to testing their transferability to other geographic regions (Rudlosky and Fuelberg 2013), assessing the operational value to forecasters (Darden et al. 2010), and applying the algorithm in conjunction with nonlightning derived measurements (Rudlosky and Fuelberg 2013).

With total lightning observations expected to become widely available among operational forecasters upon the launch of the Geostationary Lightning Mapper (GLM) onboard the GOES-R satellite in 2016, a reliable LJA holds the potential to both increase the probability of detection (POD) and decrease the false alarm rate (FAR) of severe weather warnings. Nowhere is such a forecast tool more welcomed than in regions frequently characterized by weak vertical wind shear. Weakly sheared environments are conducive to the development of single-cell thunderstorms (also termed "air mass" or "pulse" thunderstorms when threatening to produce severe weather), which present a distinct severe weather forecasting challenge. Operational forecasters possess relatively few tools for nowcasting the severity of a single-cell storm, making advanced warning difficult. Illustrating this point, Guillot et al. (2008) found that severe warning PODs are lower and FARs are higher for pulse and unorganized storms than for isolated supercells and convective lines.

LJA studies generally have not focused on the convective atmospheres in which storms form. Although some have included brief discussions of the algorithm's performance among different storm modes (Goodman et al. 2005; Schultz et al. 2011), the published research has not provided detailed documentation of an LJA's performance as a function of convective environment. Consequently, the purpose of this study is to assess the transferability of the $2 \sigma$ algorithm to difficult-to-forecast single-cell thunderstorms occurring within weakly sheared atmospheres during the summer months.

Many of the previous lightning jump studies were conducted using regional lightning mapping arrays (LMAs), and consequently, the results represent a relatively narrow range of spatial domains and severe weather climatologies/thunderstorm environments (Fig. 1). This study focuses on the utility of the LJA for detecting severe single-cell thunderstorms within weak-shear environments in place across the mountainous terrain of the central Appalachian Mountains and the neighboring piedmont (Fig. 2a,b). The method of identifying such a subset of storms was adopted from Miller et al. (2015a; hereafter M15), who based the discrimination of lightning-defined (LD) single-cell and multicell/supercell thunderstorm days on the spatiotemporal distribution of total lightning flashes. In this study, the $2 \sigma$ lightning jump algorithm was applied to all LD storms identified using the M15 spatiotemporal analysis method.

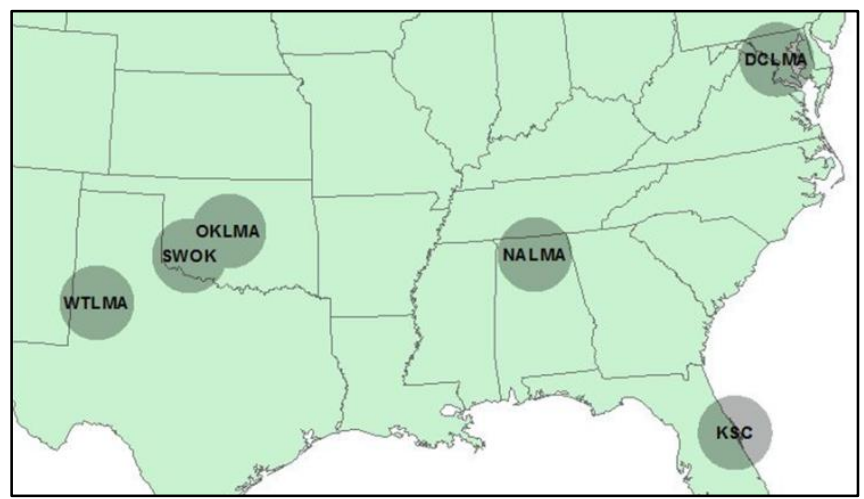

Figure 1. The geographical distribution of current LMA operational domains. The eastern Colorado-western Kansas study area included in Schultz et al. (2011) is not pictured [adapted from Filiaggi (2012)]. Click image for an external version; this applies to all figures hereafter.

The data analyzed in this study were collected during the summers of 2012 and 2013 for an area covering portions of southwestern Virginia, southeastern West Virginia and northwestern North Carolina, that roughly outlines the Blacksburg, Virginia, National Weather Service Forecasting Office (NWSFO) County Warning Area (CWA; Fig. 2a). The approximately $75630 \mathrm{~km}^{2}$ area of the study domain includes mountainous terrain to the west and lower elevation piedmont to the east (Fig. 2b). During summer, this region of the United States is frequently characterized by warm, moist air masses that give rise 

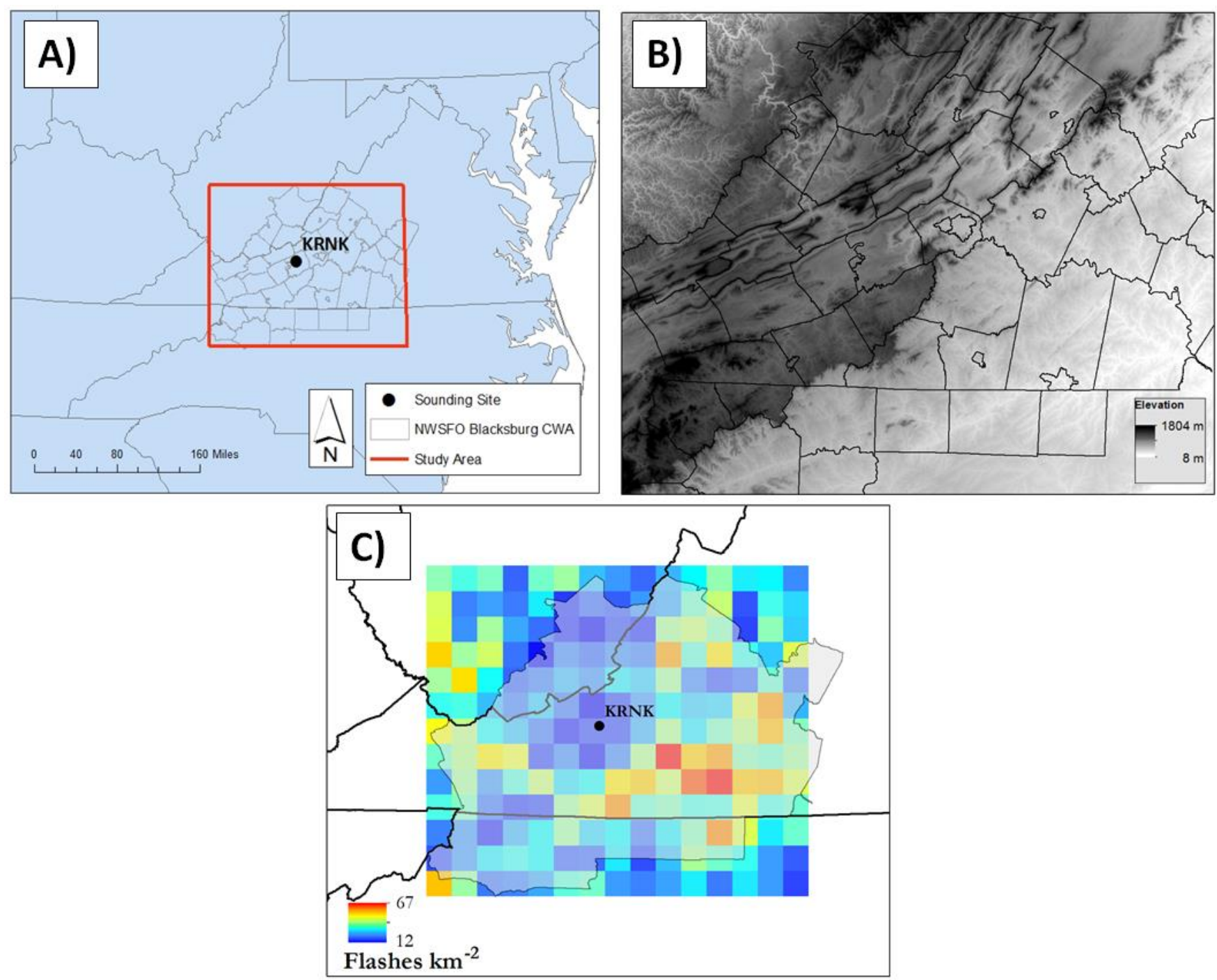

Figure 2. Study domain (a) as situated within the greater mid-Atlantic region [taken from Miller et al. (2015b)] and (b) as containing a diversity of topography. The study area covers roughly $75630 \mathrm{~km}^{2}$ with the KRNK sounding site positioned approximately in the center of the study area. Pane (c) depicts the density of lightning flashes detected during a one-year period beginning 12 October 2011 at 20 -km resolution.

to disorganized convection during the peak of daytime heating. Given the lack of organization, predicting the severity of single-cell storms is the primary summer forecasting challenge within this type of environment (Guillot et al. 2008). The results of this study aim to provide forecasters with an improved understanding of the transferability of the $2 \sigma$ jump detection algorithm to weak-shear convective regimes.

\section{Data and methods}

\section{a. Lightning data}

The Earth Networks Total Lightning Network (ENTLN) consists of 700 Earth Networks Total
Lightning Sensors (ENLS) world-wide (S. Heckman 2013, personal communication). With each ENLS capable of detecting electromagnetic frequencies between $1 \mathrm{~Hz}$ and $12 \mathrm{MHz}$ (Liu and Heckman 2011), the network can locate and classify the low-frequency waveforms emitted by CG flashes as well as the highfrequency emissions of IC flashes. Upon detection by the ENLS, waveforms are classified as either IC or $\mathrm{CG}$, and subsequently grouped into flashes if they occur within 700 milliseconds and $10 \mathrm{~km}$ of each other (Liu and Heckman 2011). All detected strokes had already been combined into flashes prior to our receipt of the ENTLN data. 
To minimize the concern that erroneous flashes are recorded in the database, 5-8 sensors must agree on the time and distance from the sensors (S. Heckman 2013, personal communication). Comparisons of the ENTLN to the Tropical Rainfall Measurement Mission (TRMM) Lightning Imaging Sensor (LIS) have revealed reasonable consistency, nearly two-thirds agreement, between the data sources over North America (Rudlosky 2014; Thompson et al. 2014). The ENTLN's detection efficiency (DE) is $>90 \%$ for CG flashes in the eastern United States, while the DE for IC flashes is roughly $70 \%$ over the study area (Liu and Heckman 2011). However, terrain effects can cause local sub-domain scale variations in IC DE (Fig. 2c). An evaluation against rocket-triggered flashes in Florida determined a median location error of $687 \mathrm{~m}$ following an upgrade of the detection algorithm (Mallick et al. 2013).

Although the ENTLN is continually being modified to increase DE, classification accuracy, and spatial accuracy, a significant upgrade to the waveform-processing algorithm occurred during the winter of 2012-2013. In addition, a very dynamic summer 2013 pattern severely limited the number of weakly sheared air masses available for study. Because the study period represented data of inconsistent integrity and summer 2013 contributed very few weak-shear environments, it was decided that only 2012 ENTLN observations would be incorporated into this LJA analysis.

\section{b. Radiosonde observations}

In order to characterize the atmospheric environment in which the lightning flashes occurred, daily 0000 UTC (2000 LT) radiosonde data were obtained for the Blacksburg, Virginia (KRNK) launch site. Situated at approximately $37.2^{\circ} \mathrm{N}, 80.4^{\circ} \mathrm{W}$ and an elevation of $654 \mathrm{~m}$, the KRNK sounding site is centrally located within the Appalachian Mountains near the middle of the study domain (Fig. 2a). Sounding data were retrieved from the University of Wyoming upper air data distribution page (weather.uwyo.edu/upperair/sounding.html). Wind shear $\left(\mathrm{m} \mathrm{s}^{-1}\right)$ over the $0-6-\mathrm{km}$ layer was calculated using the magnitude of the difference of the wind vectors at the surface and an interpolated vector six $\mathrm{km}$ above the surface. A linear interpolation was performed using the wind vectors immediately below and above the six-km level. Several studies have found that $0-6-\mathrm{km}$ wind shear offers a meaningful indication of general storm organization tendencies (e.g., Thompson et al. 2003). Days with sounding malfunctions were excluded from the statistical analyses conducted in this work. In some cases, the 0000 UTC sounding profile may have been influenced by convection occurring prior to this late-day balloon launch; however, a cursory review of precipitation data suggested that nearby convection was only present on $10.7 \%$ of the days considered (M15).

\section{c. Severe weather reports}

Severe weather reports were obtained through the National Climatic Data Center's (NCDC) Storm Data publication. Although an effort is made to qualitycontrol the reports published within Storm Data, the National Weather Service (NWS) does not guarantee the accuracy of the reports (www.ncdc.noaa.gov/ stormevents/faq.jsp). In addition to several studies that have documented temporal inconsistencies and spatial errors in the reporting of severe weather (e.g., Witt et al. 1998a,b; Williams et al. 1999), it must also be acknowledged that some severe weather events may not be documented at all. Despite these issues, Storm Data is generally regarded as the most accessible and respected severe weather archive available for analysis.

\section{Methods}

\section{a. Identifying single-cell thunderstorm days}

The process of identifying single-cell thunderstorms for the 2012 and 2013 convective seasons (1 May through 31 August) was adopted from M15. The referenced method represents a preliminary attempt at diagnosing storm mode using the spatiotemporal distribution of a storm's lightning flashes. Their methods were developed using 2012 summer season total lightning observations from the same study region used here. In this method, LD single-cell thunderstorm days are identified through a three-step process, described next.

\section{1) SPATIOTEMPORAL CLUSTERING OF TOTAL LIGHT- NING FLASHES}

All flashes observed during peak daytime heating, approximated to be 1800-0100 UTC (1400-2100 LT), were grouped into clusters via the single-linkage clustering technique (M15). The distance between each flash and all others was calculated from the threedimensional distance separating the flashes. This 
measure combined the location of a flash in $x, y$ space with the position of the flash in time space $(t)$, with the relative contribution of time to space scaled based on the spatiotemporal dimensions of an average, generic thunderstorm (M15). The single-linkage clustering, described in detail by Gong and Richman (1995), began by considering all flashes as independent clusters. Groups were then iteratively combined by merging the nearest two clusters in the sample until a desired number of remaining clusters was reached (M15). Clusters with ongoing activity at the beginning or end of the temporal range were excluded from analysis as well as any clusters that abutted the boundary of the study area (M15). The results of the clustering process for a single day in 2012 are depicted in Fig. 3.

Due to the preliminary nature of their research, M15 were forced to make several assumptions during this stage of their analysis. A different set of assumptions would likely yield a different set of clusters, and further investigation of the validity of these decisions is suggested by M15. For instance, the scaling factor used to convert the $t$ coordinate of a flash into the same dimension as the $x, y$ coordinates, the selection of the "number of desired clusters", and decisions aimed towards improving the computing efficiency of the algorithm are all postulated to hold some degree of influence over the final set of clusters determined by the single-linkage clustering algorithm (M15).

\section{2) CALCULATING A CLUSTER'S STORM INDEX (SI)}

The SI is a unit-less measure assigned to each cluster that corresponds to the degree to which the observed properties of the cluster match the expected properties of a typical single-cell thunderstorm. These "properties" of a cluster are four observables: duration, areal extent, mean motion, and shape (M15). The expected properties for a typical single-cell thunderstorm outlined by M15 were informed by observations from The Thunderstorm: Report of the Thunderstorm Project (Byers and Braham 1949) when available. Otherwise, M15 derived expectations from the total distribution of all cluster values. Table 1 displays the upper and lower bounds used in M15 to assign the individual parameter scores. For more information regarding the rationale surrounding the selection of the bounds, see M15. The individual parameter scores were combined into a single SI score using a set of relative weights that M15 determined using the Analytic Hierarchy Process (Saaty 1994) applied to survey responses from NWS forecasters from the Blacksburg forecast office. The largest possible SI score, 100, corresponds to a cluster that satisfies the most conservative expectations of a single-cell thunderstorm for all attributes (M15). Whereas a score of zero indicates that a cluster's properties fail to meet the most liberal expectations for a single-cell storm, the SI possesses no lower limit. As a cluster's attributes increasingly disagree with the typical single-cell thunderstorm values, the SI score is permitted to decay below zero accordingly (M15).

Table 1. Duration, areal extent, mean motion, and shape threshold values used by M15 to assign storm index (SI) scores to lightning clusters. Values taken from M15.

\begin{tabular}{|c|c|c|c|}
\hline Property & Upper & Lower & Source \\
\hline Duration (min) & 75.0 & 20.0 & $\begin{array}{c}\text { Byers and } \\
\text { Braham } \\
(1949)\end{array}$ \\
\hline Areal extent $\left(\mathrm{km}^{2}\right)$ & 64.7 & 51.8 & $\begin{array}{c}\text { Byers and } \\
\text { Braham } \\
(1949)\end{array}$ \\
\hline $\begin{array}{c}\text { Mean Motion } \\
\left(\mathrm{m} \mathrm{s}^{-1}\right)\end{array}$ & 5.3 & 3.0 & $\begin{array}{c}\text { Byers and } \\
\text { Braham } \\
(1949)\end{array}$ \\
\hline Shape & 0.33 & 0.55 & $\begin{array}{c}\text { Distribution } \\
\text { of all cluster } \\
\text { scores }\end{array}$ \\
\hline
\end{tabular}

\section{3) ISOLATING SINGLE-CELL THUNDERSTORM DAYS}

The discernment of single-cell thunderstorms was based upon the identification of "single-cell thunderstorm days"-days on which the simple majority of clusters where designated as LD singlecells. Lightning clusters with fewer than 100 flashes were removed from consideration. This threshold was statistically determined from a large sample of storms during the 2012 convective season (M15). Additionally, in order to be considered a storm day, at least six 100-flash events must have been identified within the study area. This combination of minimum cluster flash total and minimum daily event total delivered the most reliable relationship between median daily SI and a given day's 0000 UTC 0-6-km wind shear (M15). LD single-cell and multicell/ supercell thunderstorm days were separated based on the histogram of daily median SI scores (Fig. 4a) for all 2012-2013 storm days. An SI value equal to eight was selected as the partition between LD single-cell and multicell/supercell days so that all LD single- 


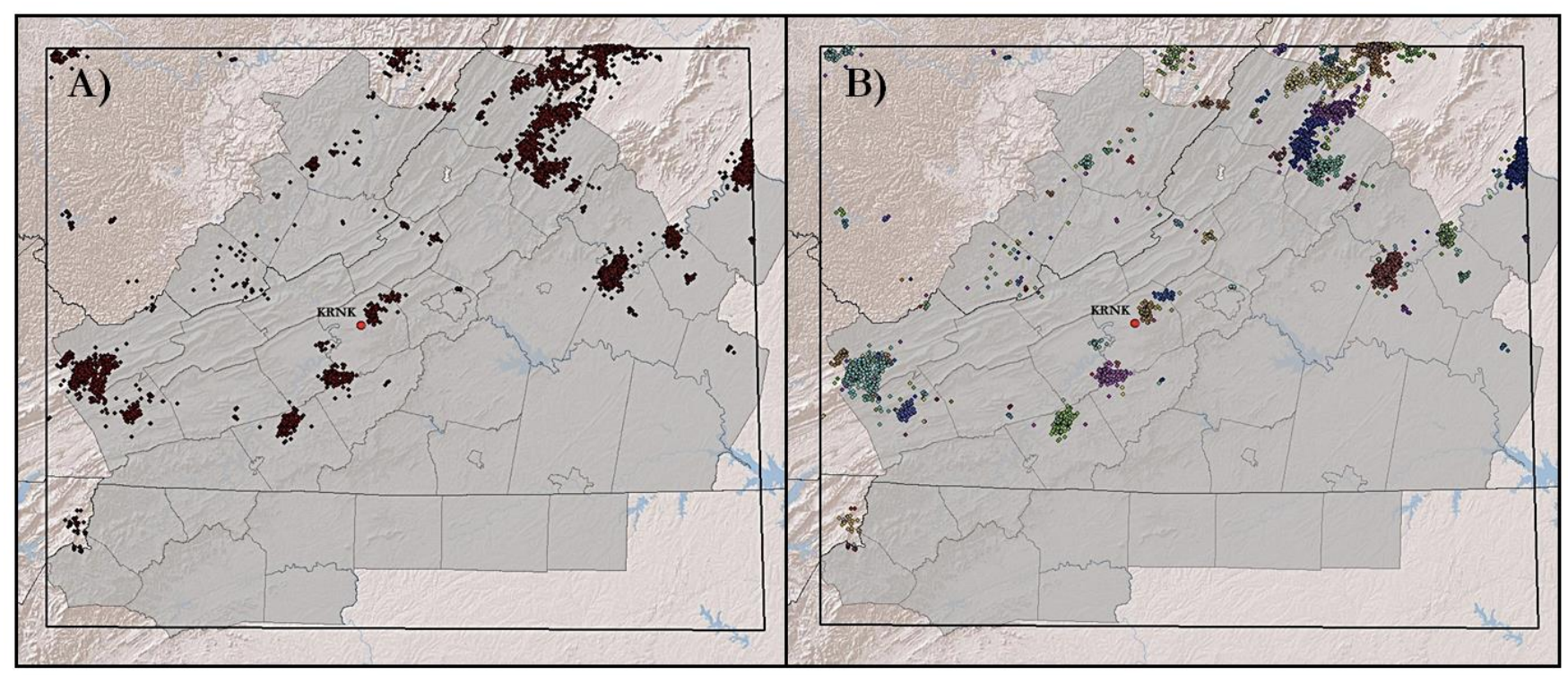

Figure 3. Lightning flashes occurring on 21 June 2012 depicted (a) prior to the single-linkage clustering procedure and (b) after the results of the clustering process. Different clusters are denoted by the color of the points. Thunderstorms appear as dense clumps of flashes and are clearly identified via the clustering technique. The KRNK radiosonde launch site is marked near the center of the images (taken from M15).

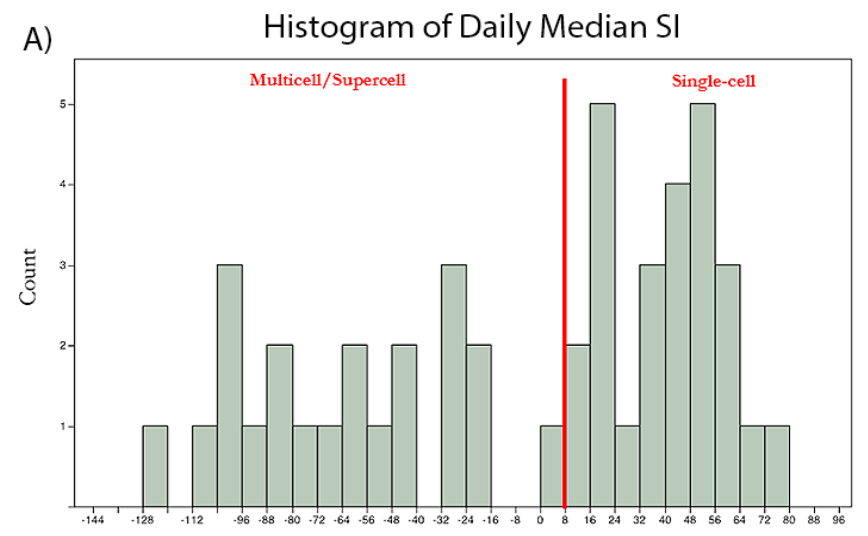

B)

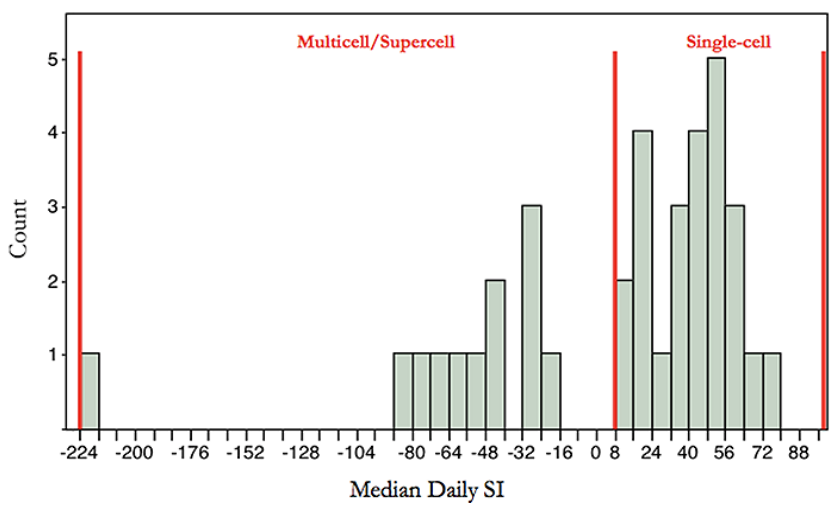

Figure 4. Histogram of median daily SI scores for the (a) 50 storm days during the summers of 2012-2013 and (b) 36 storm days during the summer of 2012. A median SI score equal to eight served as the division between LD single-cell and LD multicell/ supercell thunderstorm days. cell days would comfortably satisfy the most liberal properties of a single-cell thunderstorm.

It should be noted that M15 acknowledge that the above method represents only a preliminary attempt at storm classification via total lightning observations, and that many aspects of the procedure are open to refinement and improvement. This study followed the exact process outlined in M15, and consequently, did not investigate any of the enhancements suggested by the authors. Thus, the same limitations stated by M15 should be applied to the results of this analysis as well.

Table 2 summarizes the results of the LD singlecell and multicell/supercell storm day classification for 2012-2013. Of the 246 days during the two seasons for which data were obtained, lightning was recorded on 178 days (72.4\%). As done by M15, a pooled $t$-test for unequal variances (also known as a Welch's test) was performed to evaluate the difference in 0000 UTC $0-6-\mathrm{km}$ shear between the two categories of storm days for statistical significance. The Welch's test revealed with $99 \%$ confidence that $\mathrm{LD}$ single-cell days possessed significantly weaker wind shear $\left(7.2 \mathrm{~m} \mathrm{~s}^{-1}\right)$ than multicell/supercell days $\left(12.6 \mathrm{~m} \mathrm{~s}^{-1}\right)$, consistent with traditional definitions for single-cell storms (Markowski and Richardson 2010).

As described previously, in order to be classified as an "LD single-cell thunderstorm day", M15 required that the median SI for a day with at least six, 100-flash clusters fall within the top tier of daily 
Table 2. Median daily SI scores used to distinguish between LD single-cell and LD multicell/supercell thunderstorm days during both 2012 and 2013. The number of days and individual events falling within the SI bounds are shown. Values for 2012 only are in parenthesis.

\begin{tabular}{|c|c|c|c|}
\hline Category & SI Bounds & $\begin{array}{c}\text { Number of } \\
\text { days }\end{array}$ & $\begin{array}{c}\text { Number of } \\
\text { events }\end{array}$ \\
\hline LD Single-cell & $>8$ & $25(24)$ & $351(334)$ \\
\hline LD Multi/Super & $\leq 8$ & $25(12)$ & $235(136)$ \\
\hline
\end{tabular}

median SI scores according to the SI histogram (Fig. 4a). Although it is possible (and, indeed, it is so) that LD storms with small SI scores occurred on LD single-cell thunderstorm days, the "average" LD storm on these days was nonetheless satisfactorily shortlived, small, slow-moving, and circular in its lightning footprint. Additionally, it is important to note that of the $25 \mathrm{LD}$ single-cell storm days, 24 occurred during the 2012 convective season. However, this result was expected, considering the dynamically active atmosphere that characterized the summer of 2013 across the study area (W. Perry 2014, personal communication) and precluded widespread development of clearly identifiable single-cell storms. Given this situation, combined with the winter 2012-2013 ENTLN upgrade, 2013 ENTLN data were excluded from further analysis. Figure $4 \mathrm{~b}$ and Table 2 re-express the results of the clustering method for the 2012 season alone.

\section{b. The lightning jump algorithm}

The first generation of LJAs were developed by Gatlin and Goodman (2010), who evaluated 10000 unique combinations of possible LJA configurations upon a small sample of 20 thunderstorms. Schultz et al. $(2009,2011)$ built upon the results of Gatlin and Goodman (2010) by evaluating the performance of six LJAs applied to much larger samples. After rigorous testing, it was determined the " $2 \sigma$ algorithm" possessed the best combination of FAR and POD (Schultz et al. 2009).

As detailed by Schultz et al. (2011), the $2 \sigma$ algorithm requires that the two most recent 1-min lightning periods are averaged together, forming an average 2-min flash rate expressed in flashes $\mathrm{min}^{-1}$ (fpm). If this average exceeds $10 \mathrm{fpm}$, then the algorithm executes. Upon activation of the algorithm, six 2-min averages are calculated from the $12 \mathrm{~min}$ of total lightning activity immediately prior to the most current 2-min period. Consecutive 2-min averages are then subtracted, yielding five values representing the time rate of change of the total flash rate, DFRDT (flashes $\min ^{-2}$ ). A standard deviation $(\sigma)$ is computed from these five values, and the jump threshold is set equal to twice this value $(2 \sigma)$. The 2 -min average immediately prior to the most current 2-min average flash rate is subtracted from the most current 2-min average itself, resulting in the current DFRDT value. If this new value exceeds the jump threshold, then a lightning jump is determined to have occurred. Figure 5 depicts an example of a typical flash rate time series.

As the above procedure indicates, lightning jumps are triggered by sharp increases in the detected total flash rate of the storm. The jump, indicative of a strengthening of the storm's updraft (e.g., Gatlin and Goodman 2010), is therefore useful for anticipating severe weather. However, in the complex terrain of the study area, DE gradients along topographic boundaries (Fig. 2c) can cause artificial lightning jumps resulting from storm movement into areas of better ENTLN detection capability (e.g., Thompson et al. 2014). Fortunately, single-cell thunderstorms, the primary focus of this study, are characterized by a relative lack of movement within their weak flow regimes. Artificial jumps can weaken lightning jump performance statistics (see next section) when they occur; however, this influence is judged to be limited among the single-cell thunderstorms on which this study focuses.

\section{c. Assessing storm severity and LJA performance}

To establish a binary classification of storm severity (i.e., severe or nonsevere), the locations of severe weather reports were compared to the spatial footprint of every LD storm's total lightning activity within a geographical information system (GIS) interface, joining any overlapping reports and storms. The Environmental Systems Research Institute's (ESRI) ArcMap 10.1 served as the GIS platform for conducting the spatial components of the analysis. Successful spatial joins were isolated to only include those joins whose severe weather report occurred after the first lightning flash and before the last lightning flash during the LD storm's lifetime. A storm was deemed severe if a report fell within an LD storm's spatiotemporal bounds. If no severe weather report occurred within these bounds, then the storm was deemed nonsevere. 
Total Flash Rate Time Series

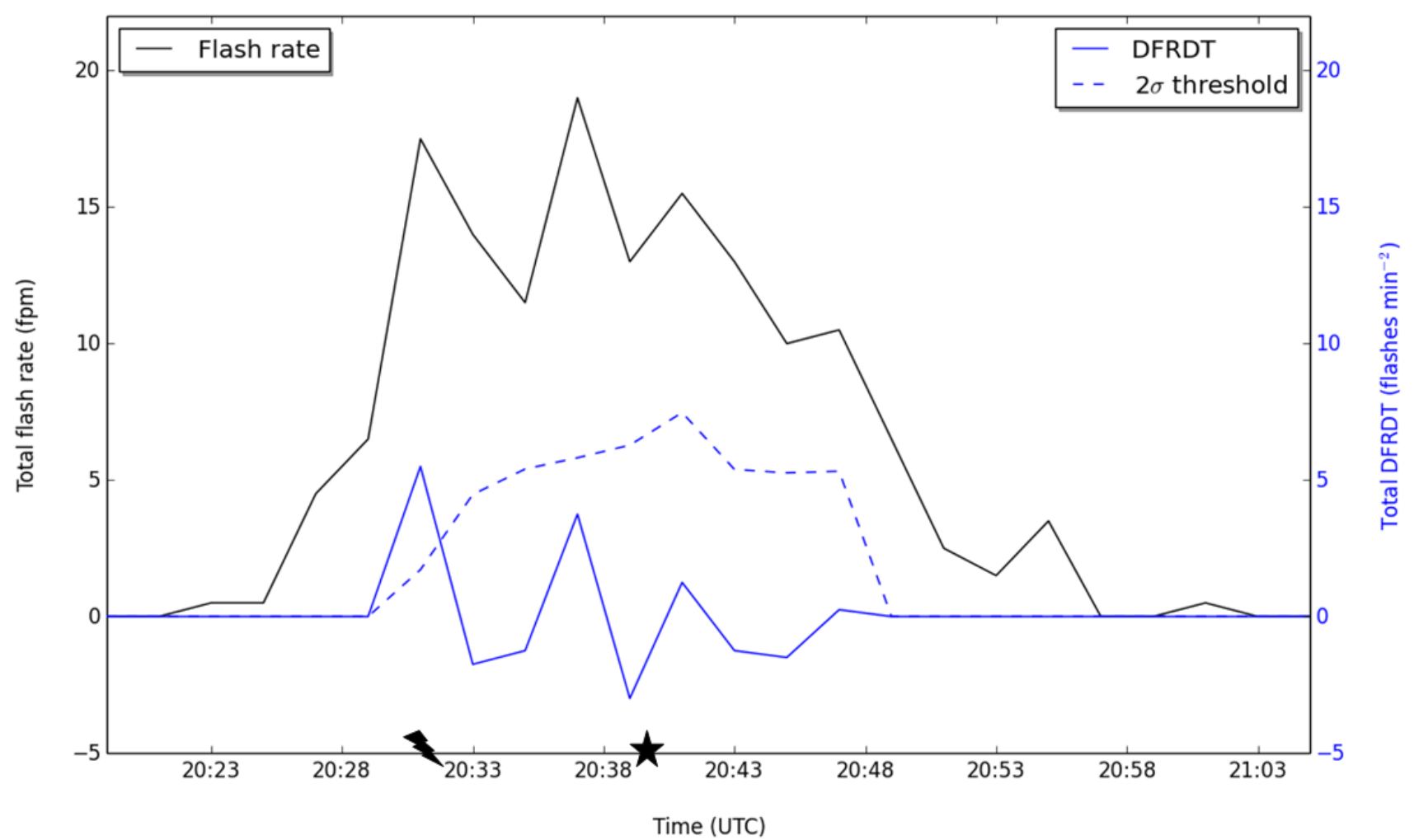

Figure 5. Flash rate time series of a thunderstorm occurring on 8 July 2012. A lightning jump (black lightning bolt) occurred at 2031 UTC, and a corresponding severe wind event (black star) was reported at 2039 UTC. The vertical axes represent values for two different units. When interpreting flash rate, the vertical axes represent fpm, but when interpreting DFRDT and $2 \sigma$ thresholds, the axes represent flashes $\min ^{-2}$.

Several possible sources of error were introduced in the spatiotemporal joining stage. For instance, many widespread severe weather events were excluded from the 470-storm pool Because they occurred partially outside of the study domain, and thus, only partial total lightning data existed for these storms. Additionally, it is possible that a severe weather event either fell outside of its storm's spatiotemporal lightning footprint, or it was produced by a cluster of $<100$ flashes. Finally, reporting errors (both spatial and temporal) within the Storm Data publication could prevent the joining of severe weather events to their parent storm. Although there is great confidence that the 53 LD storms successfully linked to severe weather events produced severe weather, it is likely that at least some of the remaining 417 LD storms not linked to a severe weather report did indeed produce severe weather. For this reason the terms "severe" and "nonsevere" should be interpreted with these qualifications hereafter.

The assignment of severe weather reports to their parent storms allows for an evaluation of the $2 \sigma$ algorithm performance. Following the method outlined by Schultz et al. (2011), once a lightning jump was identified, a virtual "warning" was placed on the storm for the next 45 minutes. If the storm produced a documented severe weather event within the warning window, then the severe event was "detected" and the responsible jump was "verified." If a severe weather event occurred without a preceding jump, it was considered "undetected," and if a jump occurred without a subsequent severe weather event within the warning window, it was deemed "unverified." To avoid over-estimating the LJA's detection capability, severe weather reports joined to the same storm and occurring within six minutes of each other were combined into a single severe weather event (Schultz et al. 2011). If more than one warning had been issued on a storm upon the observation of a severe weather event, then the verification was applied to the earliest issued warning (Schultz et al. 2011). A single severe weather report could not be used to validate more than one lightning jump warning. 
To summarize the performance of the algorithm, the following four quantities were computed: POD, FAR, critical success index (CSI), and lead time. The POD, FAR, and CSI were calculated independently for the two LD storm modes via the following formulae:

$$
\begin{aligned}
& P O D=\frac{\text { detected }}{\text { detected }+ \text { undetected }} \\
& F A R=\frac{\text { unverified }}{\text { verified }+ \text { unverified }} \\
& C S I=\frac{\text { verified }}{\text { verified }+ \text { unverified }+ \text { undetected }}
\end{aligned}
$$

Figure 6 illustrates how severe weather reports and lightning jumps interact to yield the above performance statistics. Lead time was computed by subtracting the time at which a lightning jump began from the timestamp of the subsequent severe weather event as recorded within Storm Data.

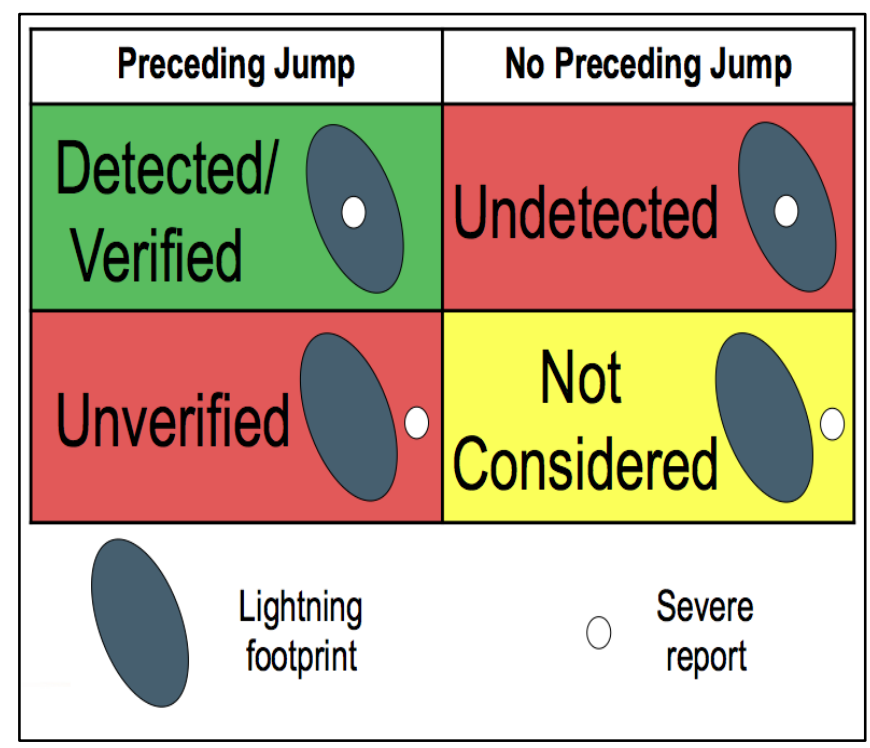

Figure 6. Visualization of the FAR and POD calculation terminology. The location of a severe weather report in relation to the spatiotemporal lightning footprint of a storm also can influence the classification of an LD storm as severe versus nonsevere.

\section{Analysis and discussion}

The $2 \sigma$ algorithm was applied to all flashes associated with each of the 470 events as determined by the M15 method. The $2 \sigma$ algorithm results are presented and discussed below as they relate to three areas: SI category, storm severity, and large-SI thunderstorms.

\section{a. Lightning patterns by SI category}

Table 3 depicts the total lightning temporal characteristics of both LD storm modes. A cursory glance reveals that although minor differences exist between values for LD single-cell and multicell/ supercell storms, there are no obvious distinctions between the lightning trends within storms of the two modes. This is confirmed by pooled $t$-tests for equal variances, which did not find significant differences between the two storm modes for their maximum total flash rates (FRs), mean DFRDT values, or mean jumps per event. Figures $7 \mathrm{a}$ and $7 \mathrm{~b}$ depict the distributions of max total FRs and mean DFRDTs, respectively.

With all metrics relating to the occurrence of total lightning jumps consistent across the two LD storm modes, attention shifted to evaluating the accuracy of the $2 \sigma$ algorithm in each group. As explained previously, severe weather reports from Storm Data were intersected with the time and space extents of all 470 LD storms as determined through the SI identification method (M15) using a GIS platform. Storm Data yielded 293 severe weather reports within the study domain on LD single-cell or multicell/ supercell days that occurred within the daily timeframe for which lightning flashes were considered (Table 4). Of these, 102 occurred within the spatiotemporal total lightning extent of a thunderstorm. Following the methods of Schultz et al. (2011), reports occurring within six minutes of each other were combined into a single severe weather event, with this consolidation yielding 85 unique severe events. Overall, $34.8 \%$ of severe weather reports were successfully paired with an LD storm. As discussed in the "Assessing storm severity and LJA performance" segment of the Methods section, there are several possible causes for unmatched Storm Data reports.

Table 5 summarizes the POD, FAR, and CSI for each of the convective categories. Whereas portions of these results compare very well to previous LJA studies, the FAR $(86.7 \%$ for LD single-cell and $90 \%$ for LD multicell/supercell) and CSI $(12.9 \%, 9.7 \%)$ values determined by this analysis differ greatly with the 36\% FAR and 55\% CSI found by Schultz et al. (2011). It is difficult to identify a single likely cause of this discrepancy. Although not the primary objective of this study, it is evident from this analysis that a successful LJA implementation requires robustness from much more than the algorithm alone. Several 
Table 3. Mean maximum total lightning FRs of all summer 2012 storms in each category, expressed in fpm. The fractions of storms with maximum FRs meeting the activation threshold established by Schultz et al. (2011) and fractions of storms producing total lightning jumps are expressed as percentages. The mean DFRDT values (flashes $\mathrm{min}^{-2}$ ) represent the average DFRDT value recorded during the entire extent of all lightning jumps within a storm. Recall that according to M15 all clusters of fewer than 100 flashes were removed.

\begin{tabular}{|c|c|c|c|c|c|}
\hline Category & Mean Max FR & $\begin{array}{c}\text { Fraction with Max } \\
\text { FR } \geq \mathbf{1 0} \mathbf{f p m}\end{array}$ & $\begin{array}{c}\text { Mean Jumps Per } \\
\text { Event }\end{array}$ & $\begin{array}{c}\text { Fraction Producing } \\
\text { Jumps }\end{array}$ & Mean DFRDT \\
\hline LD Single-cell & 28.9 & 83.5 & 1.00 & 67.6 & 4.71 \\
\hline LD Multi/Super & 32.6 & 84.6 & 1.18 & 72.1 & 4.36 \\
\hline
\end{tabular}

Table 4. Number of reports of severe hail, severe wind, and the sums of both per each SI category (2012 only). The mean reports per event were calculated by dividing the total number of raw reports occurring on the respective SI categorical days by the total number of LD storms in each category.

\begin{tabular}{|c|c|c|c|c|c|}
\hline Category & Severe Hail Reports & $\begin{array}{c}\text { Severe Wind } \\
\text { Reports }\end{array}$ & $\begin{array}{c}\text { Total Severe } \\
\text { Reports }\end{array}$ & $\begin{array}{c}\text { Mean Reports Per } \\
\text { Event }\end{array}$ & $\begin{array}{c}\text { Storms with Severe } \\
\text { Report }\end{array}$ \\
\hline LD Single-cell & 48 & 109 & 157 & 0.47 & 35 \\
\hline LD Multi/Super & 62 & 74 & 136 & 1.00 & 18 \\
\hline Total & $\mathbf{1 1 0}$ & $\mathbf{1 8 3}$ & $\mathbf{2 9 3}$ & $\mathbf{- - - - -}$ \\
\hline
\end{tabular}

Table 5. Number of severe weather events and values of POD, FAR, CSI (percentages), and lead time (minutes) for each SI category after combining severe reports occurring within six minutes of each other (2012 only).

\begin{tabular}{|c|c|c|c|c|c|}
\hline Category & $\begin{array}{c}\text { Severe } \\
\text { Events }\end{array}$ & Tot. POD & Tot. FAR & $\begin{array}{c}\text { Mean Tot. Lead } \\
\text { Time } \pm \text { Std. Dev. }\end{array}$ \\
\hline LD Single-cell & 59 & 88.1 & 86.7 & 12.9 & $22.15 \pm 12.15$ \\
\hline LD Multi/Super & 26 & 80.8 & 90.0 & 9.7 & $23.42 \pm 14.69$ \\
\hline
\end{tabular}

interacting factors such as the storm cell identification method, the total lightning observation system, and the geographic domain, all contribute to the success or failure of an operational LJA. Future work might seek to examine the robustness of the overall LJA implementation to changes in these sub-components.

Even though the PODs found with this analysis $(88.1 \%, 80.8 \%)$ compare well to those calculated by Schultz et al. (2011; 78.1\% for all storm types), the much larger FARs decreased CSIs to near $10 \%$. Additionally, while lead times were very comparable to Schultz et al. (2011), large standard deviations in the values found here remove most practical value from the mean. Although performance statistics were expected to at least slightly differ across the LD categories, the large FARs within both convective environments are cause for concern.

\section{b. Severe versus nonsevere thunderstorm lightning trends}

Linking severe weather events to their parent thunderstorms allows comparisons of the lightning behavior between severe and nonsevere storms. The separation of storms into severe and nonsevere categories provides further insight into the potentially unique lightning behavior of the more dangerous thunderstorms. Although severe thunderstorms were successfully linked to a severe weather event, it is possible that some "nonsevere" thunderstorms did, in reality, produce severe weather. However, based on the total lightning jump and frequency characteristics expressed in Table 6, the accidental inclusion of unverified severe storms in the nonsevere sample would likely only have inflated the metrics calculated for the nonsevere thunderstorm sample to values closer to those for the sample of severe storms. Thus, the general tendency would likely remain unaffected by any misclassifications; only the magnitude of the difference would be influenced.

The mean maximum total FR and mean total DFRDT is greater for severe than nonsevere storms. Pooled $t$-tests for unequal variances confirm statistically significant differences with $95 \%$ confidence. Figures $6 \mathrm{c}$ and $6 \mathrm{~d}$ depict the distributions 


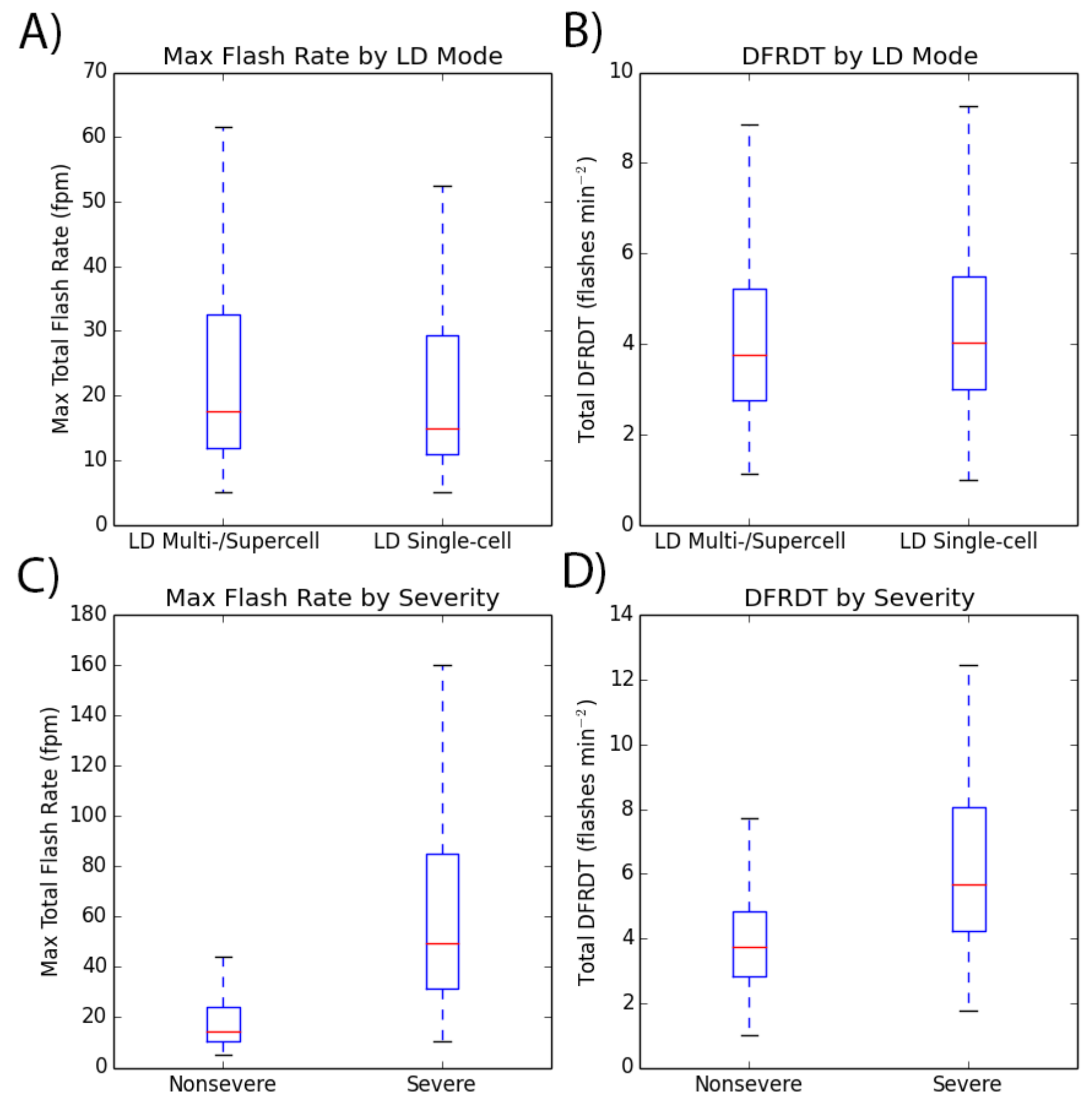

Figure 7. Box plots indicating the distribution of (a) maximum total flash rates by LD storm mode, (b) total DFRDTs by LD storm mode, (c) maximum total flash rates by severity, and (d) total DFRDTs by severity. The DFRDT values represent the mean DFRDT value recorded during the entirety of all active lightning jumps within a storm. Red lines mark the median value. Outliers are not shown.

of these quantities. The total FR measures confirm many previous studies in which severe thunderstorms were characterized by greater FRs than nonsevere storms (e.g., Williams et al. 1999; Schultz et al. 2011; Rudlosky and Fuelberg 2013). Figure 7c indicates that roughly $75 \%$ of nonsevere LD thunderstorms possessed maximum FRs below $25 \mathrm{fpm}$ while $75 \%$ of severe LD thunderstorms possessed maximum FRs above $25 \mathrm{fpm}$. This result anecdotally suggests that 25 fpm might provide a general FR threshold differentiating nonsevere storms from potentially severe storms in the central Appalachians region. Coincidentally, a 25-fpm base threshold is currently employed by Earth Networks to issue its proprietary 
Table 6. Comparison of lightning frequency and lightning jump metrics between severe and nonsevere LD storms occurring during summer 2012. The values in this table were produced in identical fashion to their corresponding quantities in Table 3 and are displayed in the same units. Equivalent values from Rudlosky and Fuelberg (2013) are included in parenthesis for reference (when available).

\begin{tabular}{|c|c|c|c|c|c|c|}
\hline Category & Events & $\begin{array}{c}\text { Fraction } \\
\text { Producing Jump }\end{array}$ & $\begin{array}{c}\text { Mean Max Tot. } \\
\text { FR }\end{array}$ & $\begin{array}{c}\text { Tot. Jumps Per } \\
\text { Storm }\end{array}$ & $\begin{array}{c}\text { Tot. Jumps Per } \\
\text { Hour }\end{array}$ & $\begin{array}{c}\text { Mean Tot. } \\
\text { DFRDT }\end{array}$ \\
\hline Nonsevere & $417(868)$ & $65.5(53.7)$ & $22.10(--)$ & $0.90(--)$ & $1.13(0.92)$ & $4.18(9.9)$ \\
\hline Severe & $53(384)$ & $96.2(83.9)$ & $78.93(--)$ & $2.25(--)$ & $1.47(1.44)$ & $6.90(15.9)$ \\
\hline
\end{tabular}

Dangerous Thunderstorm Alerts (DTAs); however, this value is adjusted seasonally and geographically based on network $\mathrm{DE}^{2}$ (M. Hoekzema 2014, personal communication). Although the identification of a severe versus nonsevere FR threshold is not the objective of this study, the similarity of these two values warrants further investigation.

The recent work of Rudlosky and Fuelberg (2013) focuses on lightning and radar-derived measurements of a large sample of both severe and nonsevere storms within the nearby mid-Atlantic region (specifically, the greater District of Columbia area including mountainous terrain to the west). Given the similarity of our analysis, the results of their work provide a useful standard of comparison (Table 6). Although Rudlosky and Fuelberg (2013) did not calculate POD, FAR, CSI, or lead time, their study did produce somewhat similar values for the fraction of nonsevere storms recording a total lightning jump. This fraction, $65.5 \%$ from this current analysis and $53.7 \%$ from Rudlosky and Fuelberg (2013), is a key statistic contributing to the aforementioned $2 \sigma$ algorithm's large FAR. Ideally, no storm lacking severe weather would produce a total lightning jump while all severe storms would produce total lightning jumps in a 1:1 ratio with severe weather events. In order for the FAR of an LJA to be reduced toward operationally acceptable levels, the fraction of nonsevere storms producing a lightning jump will need to be reduced. Though Rudlosky and Fuelberg's (2013) DFRDTs are roughly twice as large as those found herein, the values here compare well to DFRDT magnitudes shown in Schultz et al. (2011).

Figure 8 displays the distributions of SI scores for

\footnotetext{
${ }^{2}$ Earth Networks increases the DTA flash rate threshold for the eastern United States from $25 \mathrm{fpm}$ to $40 \mathrm{fpm}$ between March and November. Thus, the potential $25 \mathrm{fpm}$ differentiator found in this analysis, though comparable to the base threshold, is smaller than the seasonally equivalent value employed over the study domain.
}

severe thunderstorms in each of the LD storm mode categories. Most noteworthy is the distribution of SI scores for severe LD single-cell storms. These storms were broadly defined as thunderstorms occurring on days in which the median cluster fell within the spatial and temporal limits of a plausibly single-cell storm. However, Fig. 8a indicates the majority of severe LD single-cell storms (also known as pulse thunderstorms) were unlike the median storms occurring on those days. In fact, only $31.4 \%$ of LD pulse storms possessed SIs greater than zero, the lower cut-off for a plausibly single-cell thunderstorm. Practically, this means that most LD pulse storms were larger, longerlasting, more linear, and faster-moving than typical single-cell thunderstorms. Figure $8 \mathrm{~b}$ displays the distribution of SI scores by storm severity, and confirms expectations that severe storms are more organized according to their SI scores than nonsevere storms. Based on Fig. 8, the performance of the $2 \sigma$ algorithm was evaluated within a subset of LD singlecell storms whose SI scores suggested that they most closely adhered to single-cell expectations.

\section{c. Lightning trends in single-cell thunderstorms}

Up to this point, statistics have been provided for both LD storm modes to provide additional context for the LD single-cell values. However, the purpose of this study is ultimately to assess the utility of the algorithm in a weak-shear environment. Thus, summary statistics were generated for the 140 storms occurring on LD single-cell storm days whose SI scores were $\geq 50$ (Table 7). This sample represents storms that adhered closely to the expected spatiotemporal characteristics of a single-cell thunderstorm that also occurred on days in which the majority of observed LD storms also satisfactorily adhered to these expectations. Because some storms within the broader LD single-cell category might actually represent multiple updrafts that developed into a multicell cluster (yet were indistinguishable by 
A)

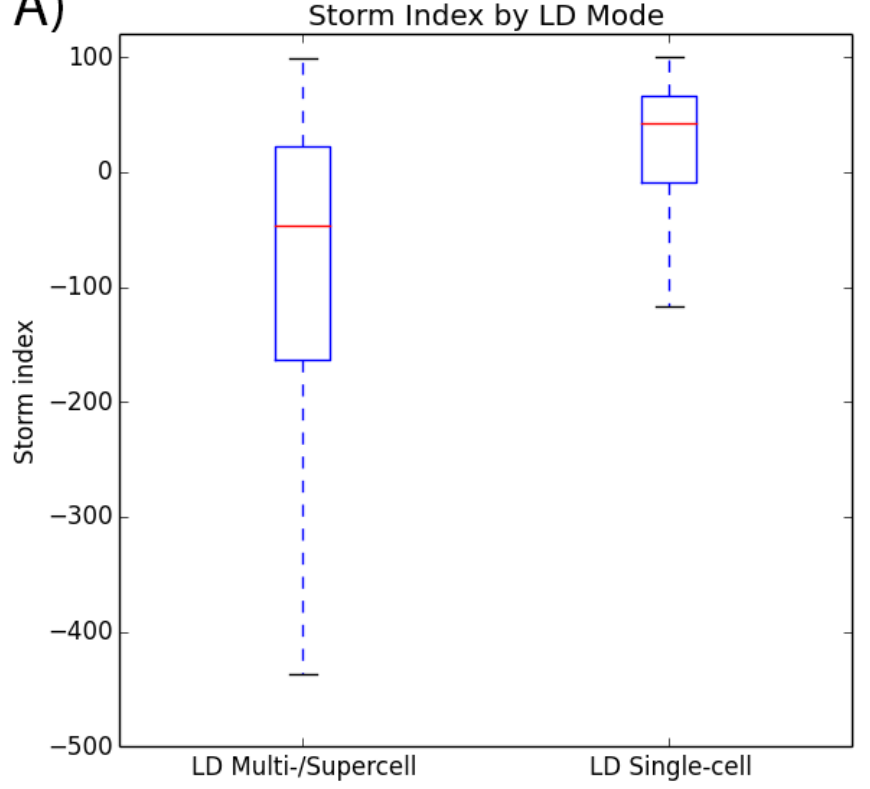

B)

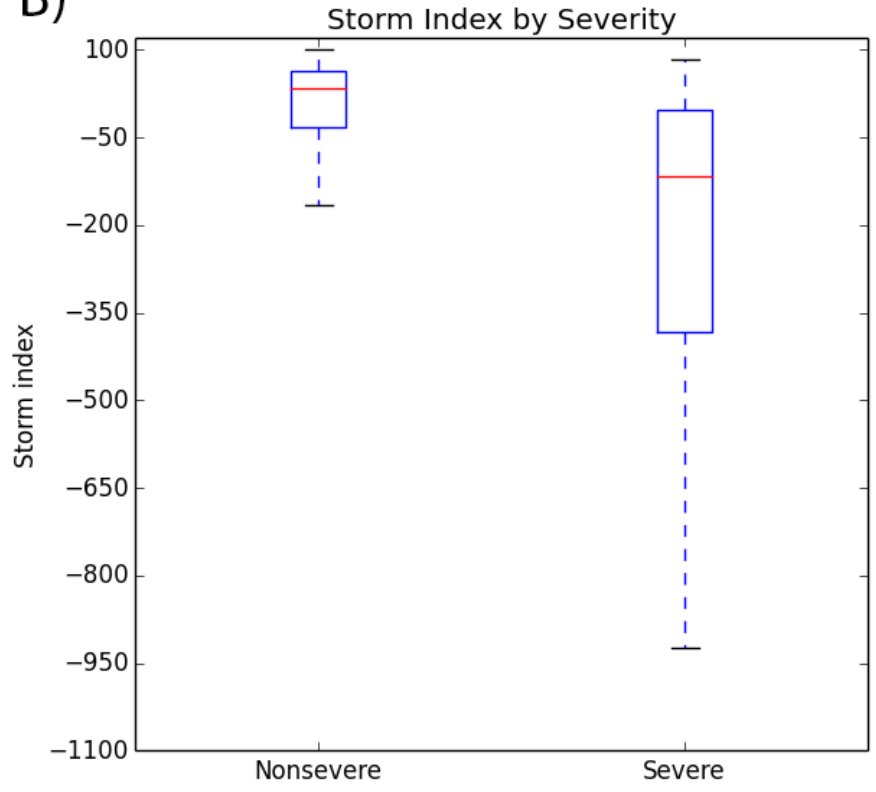

Figure 8. Box plots of SI scores for (a) severe thunderstorms by storm category and (b) all storms by severity. Outliers are not shown.

Table 7. Summary statistics for the 140 LD single-cell storms occurring during summer 2012 with SI scores $\geq 50$. All quantities were calculated in an identical fashion and expressed in the same units as those in previous tables.

\begin{tabular}{|c|c|c|c|c|c|c|}
\hline Mean Max Total FR & $\begin{array}{c}\text { Fraction with } \\
\text { Max Tot. FR } \geq \\
\mathbf{1 0} \mathbf{f p m}\end{array}$ & $\begin{array}{c}\text { Mean Tot. } \\
\text { DFRDT }\end{array}$ & $\begin{array}{c}\text { Fraction } \\
\text { Producing Tot. } \\
\text { Jump }\end{array}$ & $\begin{array}{c}\text { Tot. Jumps Per } \\
\text { Event }\end{array}$ & Tot. FAR & Tot. POD \\
\hline 15.6 & 80.0 & 4.23 & 58.6 & 0.69 & 94.8 & 75.0 \\
\hline
\end{tabular}

their total lightning footprints), the more stringent SI threshold was applied to help ensure that these 140 storms did not possess additional organization that is uncharacteristic of a single-cell thunderstorm.

The results in Table 7 indicate that the subset of LD single-cell storms with SI scores $\geq 50$ appear to produce less lightning compared to the broader group of storms occurring on LD single-cell days. Six of the seven values displayed in Table 7 are smaller than their corresponding values for the broader LD singlecell category (Table 3) while the only greater quantity, FAR, reflects poorer algorithm performance. These results are confirmed with pooled $t$-tests for unequal variances that identified statistically significant decreases in maximum total FR (15.6 fpm versus 28.9 fpm) and the number of total lightning jumps per LD thunderstorm (0.69 versus 1.00$)$ with $95 \%$ confidence when considering large-SI storms on LD single-cell days. When compared to the LD multicell/supercell category (Table 3), maximum total FRs (15.6 fpm versus $32.6 \mathrm{fpm}$ ) and the number of total lightning jumps per LD storm (0.69 versus 1.18) for the 140storm subset also possessed a statistically significant decrease. Additionally, POD (75.0\% versus $88.1 \%$ and $80.8 \%)$ decreases and FAR $(94.8 \%$ versus $86.7 \%$ and $90.0 \%$ ) increases compared to the all-LD single-cells and LD multicell/supercells (Table 3).

The poorer performance of the algorithm within this subset of the clearest single-cell storms is closely related to the number of severe storms (only seven) within the 140-storm sample. Whereas $10.5 \%$ (35/334) of storms in the broader LD single-cell category were linked to severe weather reports, only $5.0 \%$ (7/140) of storms in the 140-storm subset of the purest single-cell storms were classified as severe. Although the frequency of lightning jumps (0.69 jumps per storm) also decreased within the subset, they remained much more frequent than the occurrence of severe weather at the surface $(0.10$ severe events per storm), and thus produced a large number of false alarms.

An attempt was made to decrease the high FAR values within the subset by increasing the DFRDT threshold required to initiate a jump from $2 \sigma$ to $2.5 \sigma$, $3 \sigma, 3.5 \sigma$, and $4 \sigma$. By increasing the threshold, it was hypothesized that fewer storms would meet the minimum DFRDT required to trigger a jump. Whereas 
these thresholds might decrease FAR, it is likely that POD would also decrease as a result of fewer jumps occurring. This intuitive relationship between FAR and POD was previously documented in Schultz et al. (2009); however, the referenced study did not evaluate a sigma algorithm with a coefficient greater than three. The results of the increased sigma thresholds upon the subset 140 single-cell storms are displayed in Table 8 . Whereas the larger threshold total lightning algorithms performed marginally better according to the CSI within our framework, there was no practical improvement that might be useful in an operational setting. As hypothesized, POD decreased as the sigma threshold was increased.

Table 8. Sigma algorithm performance statistics for storms occurring on 2012 LD single-cell storm days with SI scores $\geq 50$. All quantities were calculated in an identical fashion and expressed in the same units as those in previous tables. Because the pool of 140 storms only produced 12 severe weather events for calculation of POD, some POD values recur.

\begin{tabular}{|c|c|c|c|}
\hline Sigma Coefficient & Tot. POD & Tot. FAR & Tot. CSI \\
\hline 2 & 75.0 & 94.8 & 5.1 \\
\hline 2.5 & 75.0 & 94.0 & 5.7 \\
\hline 3 & 58.3 & 94.0 & 5.5 \\
\hline 3.5 & 58.3 & 92.6 & 6.8 \\
\hline 4 & 58.3 & 91.8 & 7.4 \\
\hline
\end{tabular}

It is evident from Tables 7 and 8 that all versions of the sigma algorithm evaluated within our framework identify jumps at a greater frequency than severe weather events associated with large-SI LD single-cell thunderstorms. Although the $2 \sigma$ algorithm's performance was unsatisfactory on LD single-cell and multicell/supercell days, it nonetheless performed more accurately across the broader range of thunderstorms than when applied to a subset of the smallest, most short-lived, slowest-moving, and most circular LD single-cell thunderstorms.

\section{d. Performance of the $2 \sigma$ algorithm relative to pre- vious research}

As mentioned earlier, Although PODs and lead times calculated in this study compare well to Schultz et al. (2011), the FARs produced here are substantially greater. Because the definition of the algorithm remained constant for both analyses, the significant design differences between this study and that of Schultz et al. (2011) are the 1) process used to identify thunderstorms and assign flashes to those storms, 2) the total lightning data source, 3) the study domain, and 4) the near-storm environment being considered. Though the algorithm performed most poorly among the subset of the least organized LD storms, its FAR across all environments is in stark contrast to the values determined by Schultz et al. (2011). In terms of study area, the rugged terrain and low population density of portions of the Blacksburg NWSFO CWA may have caused artificial jumps and reduced the likelihood of receiving severe weather reports from the public. However, while artificial jumps and underreporting might lead to an increase in FAR, it is unlikely that these possibilities alone would account for the dramatic differences in FAR observed in this work. Thus, it would seem that the method of identifying storms and assigning flashes, the total lightning data source, or a combination of these two factors is responsible for much of the discrepancy.

Schultz et al. (2011) identified and assigned flashes to the 711 thunderstorms of their sample using the radar tracking-based techniques of Schultz et al. (2009) (C. Schultz 2014, personal communication), a significantly different technique than the cluster-based method utilized here. The highly automated process of clustering flashes into groups may be at least partially responsible for the larger FARs documented in this study. The theorized importance of cell definition/flash appropriation echoes the results of Steiger et al. (2007), who suggested that cells within mesoscale convective systems (MCS) possessed weaker correlations between severe wind events, radar, and lightning storm cell characteristics than supercells due to lightning and reflectivity contamination from nearby cells within the MCS.

As part of the Hazardous Weather Testbed, thunderstorm identification and flash appropriation techniques have been integrated with real-time total lightning data in order to maximize the lightning jump's benefit to NWS forecasters (Calhoun 2015). Additionally, Chronis et al. (2015) compared radarbased intensity metrics between lightning jumpproducing storms and non-jump-producing storms to also demonstrate the potential for operational integration. Though these efforts bode well for the operational future of the lightning jump, the direct influence of storm identification/flash appropriation decisions on LJA accuracy also represent areas of 
further investigation as the LJA continues to be refined towards operational implementation.

The second possible factor influencing the increased FARs is the ENTLN data source. Schultz et al. (2011) utilized total lightning observations from several regional LMAs and provided ample detail regarding the procedures by which flashes were identified from VHF source points. In this study, all VHF waveforms had already been grouped into flashes by the ENTLN, as explained by Liu and Heckman (2011). Once again, the robustness of an LJA to changes in the input data source will need to be investigated further, especially considering the GLM will represent yet another total lightning observation platform. Fortunately, the near uniform spatial coverage of the GLM (Goodman et al. 2013) will aid in this endeavor considerably. Future research could seek to calculate LJA accuracy among a common set of thunderstorms between two different total lightning datasets to assess the sensitivity of LJA performance to the input data. Although it might be assumed that these factors are secondary to the selection of an algorithm itself, our study highlights that an LJA implementation is a delicate balance of several interacting sub-components. Modifications to any single element can significantly influence the resulting accuracy of the algorithm. Future LJA research should be careful to consider the algorithm as just one of several interacting elements including storm environment, storm definition, flash appropriation, and the total lightning data source.

\section{Conclusions}

Single-cell thunderstorms are frequent summertime convective phenomena that occasionally endanger human life and property in the form of severe weather. Although these ordinary thunderstorms are not consistent producers of severe weather, they do represent a significant summer forecasting challenge for NWS forecasters. Recent studies have produced encouraging results suggesting that total lightning jumps might provide a useful operational warning tool for assessing the impending severity of thunderstorms across a variety of storm environments (Goodman et al. 2005; Schultz et al. 2011).

This study evaluated the performance of the standard $2 \sigma$ lightning jump algorithm (Schultz et al. 2009,2011 ) in both weakly sheared and more strongly sheared environments to evaluate the transferability of the $2 \sigma$ algorithm to disorganized convective regimes.
The results corroborate several aspects of previous LJA studies; however, FARs across both regimes were $>85 \%$, with values for large-SI LD single-cell storms exceeding 90\%-much larger than previously documented (Schultz et al. 2011). Additionally, severe thunderstorms occurring within a weakly sheared atmosphere appear to resemble longer-lived multicell complexes more so than discrete single-cell thunderstorms.

Although an acceptably small FAR was documented by Schultz et al. (2011), this analysis did not replicate their results. Whereas the $2 \sigma$ algorithm configuration failed to deliver an acceptable level of accuracy within our framework, the statistically significant differences in total flash rate and DFRDT between severe and nonsevere storms suggest that total lightning behavior certainly holds the potential to help inform forecasters of imminent severe weather. The results indicate that $25 \mathrm{fpm}$ could provide an anecdotal threshold differentiating between severe and nonsevere convection. Although this value is much smaller than the $60 \mathrm{fpm}$ suggested by Williams et al. (1999), it is very similar to the base flash rate threshold employed by the Earth Networks' DTA, and this relationship merits further investigation. Thought an LJA implementation is much more than a single flash rate threshold [i.e., warnings issued based purely on FR threshold exceedance have also struggled with POD and FAR (e.g., Meyer et al. 2015)], the potential utility of $25 \mathrm{fpm}$ as a regionally useful indicator for the central Appalachians should be explored.

The research question posed by this study dealt solely with the transferability of the algorithm across a broader range of convective regimes, but perhaps its most useful conclusions relate to the influence of the data processing techniques upon LJA accuracy. Though spatial and temporal inaccuracies within Storm Data might have biased LJA performance statistics within our framework, this factor is theorized to be secondary to the influence of broader design decisions of our study. Specifically, differences in either the methods of identifying thunderstorms and appropriating flashes or the use of different total lightning datasets are thought to be responsible for the large discrepancy in FAR between this analysis and Schultz et al. (2011). Thus, future research might consider isolating the influence of these two factors. This is especially wise considering that all NWS offices have the ability to access ENTLN observations (although relatively few have access to real-time LMA data) and that if the algorithm becomes operation- 
alized, a standard and accurate method of identifying storms and their associated flashes will be required.

Acknowledgments. This material was based upon work supported by the COMET Program of the University Corporation for Atmospheric Research (UCAR) and the National Oceanic and Atmospheric Administration (NOAA) NWS under Grant No. Z13-99434. Any opinions, findings, conclusions, or recommen-dations expressed in this material are those of the authors and do not necessarily reflect the views of the COMET Program, UCAR, NOAA, or the NWS. Reference to any specific commercial products, process, or service by trade name, trademark, manufacturer, or otherwise, does not constitute or imply its recommendation, or favoring by the United States Government or NOAA/NWS. Use of information from this publication shall not be used for advertising or product endorsement purposes. The authors thank the staff at Earth Networks, Inc. for supplying the lightning data used in this work, as well as Chris Schultz and an anonymous reviewer whose comments greatly strengthened the content of this paper.

\section{REFERENCES}

Boccippio, D. J., K. L. Cummins, H. J. Christian, and S. J. Goodman, 2001: Combined satellite- and surface-based estimation of the intracloud-cloud-to-ground lightning ratio over the continental United States. Mon. Wea. Rev., 129, 108-122, CrossRef.

Byers, H. R., and R. R. Braham, 1949: The Thunderstorm. U.S. Government Printing Office, Washington, DC, $287 \mathrm{pp}$.

Calhoun, K. M., 2015: Forecaster use of total lightning data for short-term forecasts and warnings in the Hazardous Weather Testbed. Preprints, Seventh Conf. on the Meteorologi-cal Applications of Lightning Data, Phoenix, AZ, Amer. Meteor. Soc., 3.5. [Available online at ams.confex.com/ams/95Annual/videogate way.cgi/id/29647? recordingid=29647.]

Chronis, T., L. D. Carey, C. J. Schultz, E. V. Schultz, K. M. Calhoun, and S. J. Goodman, 2015: Exploring lightning jump characteristics. Wea. Forecasting, 30, 23-37, CrossRef.

Darden, C. B., D. J. Nadler, B. C. Carcione, R. J. Blakeslee, G. T. Stano, and D. E. Buechler, 2010: Utilizing total lightning information to diagnose convective trends. Bull. Amer. Meteor. Soc., 91, 167-175, CrossRef.

Filiaggi, T., 2012: Lightning jump evaluation: RITT Presentation. NWS, Meteorological Development Laboratory, 19 pp. [Available online at vlab.ncep.noaa.gov/documents/10157/137122/Lightnin gJumpEvaluationRITTPart2 18Dec13.pdf/caed84385bf5-4a9f-8168-3e03abfae8cc.]
Gatlin, P. N., 2007: Severe weather precursors in the lightning activity of Tennessee Valley thunderstorms. M.S. thesis, Dept. of Atmospheric Sciences, University of Alabama, $99 \mathrm{pp}$.

, and S. J. Goodman, 2010: A total lightning trending algorithm to identify severe thunderstorms. J. Atmos. Oceanic Technol., 27, 3-22, CrossRef.

Gong, X., and M. B. Richman, 1995: On the application of cluster analysis to growing season precipitation data in North America east of the Rockies. J. Climate, 8, 897931, CrossRef.

Goodman, S. J., D. E. Buechler, P. D. Wright, and W. D. Rust, 1988: Lightning and precipitation history of a microburst-producing storm. Geophys. Res. Lett., 15, 1185-1188, CrossRef. , and Coauthors, 2005: The North Alabama Lightning Mapping Array: Recent severe storm observations and future prospects. Atmos. Res., 76, 423-437, CrossRef. and _, 2013: The GOES-R Geostationary Lightning Mapper (GLM). Atmos. Res., 125-126, 3449, CrossRef.

Guillot, E. M., T. M. Smith, V. Lakshmanan, K. L. Elmore, D. W. Burgess, and G. J. Stumpf, 2008: Tornado and severe thunderstorm warning forecast skill and its relationship to storm type. Preprints, 24th Int. Conf. on Interactive Information Processing Systems for Meteorology, Oceanography, and Hydrology, New Orleans, LA, Amer. Meteor. Soc., 4A.3. [Available online at ams.confex.com/ams/pdfpapers/132244.pdf.]

Liu, C., and S. Heckman, 2011: The application of total lightning detection and cell tracking for severe weather prediction. Preprints, Fifth Conf. on the Meteorological Applications of Lightning Data, Seattle, WA, Amer. Meteor. Soc., 8.2. [Available online at ams.confex.com/ ams/91Annual/flvgateway.cgi/id/17419?recordingid=17 419.]

MacGorman, D. R., D. W. Burgess, V. Mazur, W. D. Rust, W. L. Taylor, and B. C. Johnson, 1989: Lightning rates relative to tornadic storm evolution on 22 May 1981. J. Atmos. Sci., 46, 221-250, CrossRef.

, I. R. Apostolakopoulos, N. R. Lund, N. W. S. Demetriades, M. J. Murphy, and P. R. Krehbiel, 2011: The timing of cloud-to-ground lightning relative to total lightning activity. Mon. Wea. Rev., 139, 3871-3886, CrossRef.

Mallick, S., and Coauthors, 2013: Calibration of the ENTLN against rocket-triggered lightning data. International Symposium on Lightning Protection, Belo Horizonte, Brazil, IEEE, 39-46, CrossRef.

Markowski, P., and Y. Richardson, 2010: Mesoscale Meteorology in Midlatitudes. Wiley-Blackwell, 407 pp., CrossRef.

Meyer, T. C., R. E. DiLuzio, M. Elliot, and K. M. Calhoun, 2015: Verification of Earth Network's Dangerous Thunderstorm Alerts and National Weather Service warnings. Preprints, Seventh Conf. on the Meteorologi- 
cal Applications of Lightning Data, Phoenix, AZ, Amer. Meteor. Soc., 11.5. [Available online at ams.confex.com/ams/95Annual/videogateway.cgi/id/29 019? recordingid $=29019$.]

Miller, P., A. W. Ellis, and S. Keighton, 2015a: A preliminary assessment of using spatiotemporal lightning patterns for a binary classification of thunderstorm mode. Wea. Forecasting, 30, 38-56, CrossRef.

$\ldots$ _ $\ldots$ and 2015b: Spatial distribution of lightning associated with low-shear thunderstorm environments in the central Appalachians region. Phys. Geography, 36, 127-141, CrossRef.

Rudlosky, S. D., 2014: Evaluating ground-based lightning detection networks using TRMM/LIS observations. Preprints, 23rd International Lightning Detection Conf., Tucson, AZ, Vaisala, 7 pp. [Available online at www.vaisala.com/Vaisala\%20Documents/Scientific\%2 0papers/2014\%20ILDC\%20ILMC/ILDC-

Wednesday/Rudlosky-Evaluating\%20GroundBased\%20Lightning\%20Detection\%20Networks\%20us ing\%20TRMM\%20and\%20LIS\%20Observations2014-ILDC-ILMC.pdf.]

, and H. E. Fuelberg, 2013: Documenting storm severity in the mid-Atlantic Region using lightning and radar information. Mon. Wea. Rev., 141, 3186-3202, CrossRef.

Saaty, T. L., 1994: How to make a decision: The analytic hierarchy process. Interfaces, 24, 19-43, CrossRef.

Schultz, C. J., W. A. Petersen, and L. D. Carey, 2009: Preliminary development and evaluation of lightning jump algorithms for the real-time detection of severe weather. J. Appl. Meteor. Climatol., 48, 2543-2563, CrossRef. , and 2011: Lightning and severe weather: A comparison between total and cloud-to-ground lightning trends. Wea. Forecasting, 26, 744-755, CrossRef.

Steiger, S. M., R. E. Orville, and L. D. Carey, 2007: Total lightning signatures of thunderstorm intensity over North Texas. Part II: Mesoscale convective systems. Mon. Wea. Rev., 135, 3303-3324, CrossRef.

Thompson, K. B., M. G. Bateman, and L. D. Carey, 2014: A comparison of two ground-based lightning detection networks against the satellite-based Lightning Imaging Sensor (LIS). J. Atmos. Oceanic Technol., 31, 21912205, CrossRef.

Thompson, R. L., R. Edwards, J. A. Hart, K. L. Elmore, and P. Markowski, 2003: Close proximity soundings within supercell environments obtained from the Rapid Update Cycle. Wea. Forecasting, 18, 1243-1261, CrossRef.

Williams, E., and Coauthors, 1999: The behavior of total lightning activity in severe Florida thunderstorms. Atmos. Res., 51, 245-265, CrossRef.

Witt, A., M. D. Eilts, G. J. Stumpf, J. T. Johnson, E. D. Mitchell, and K. W. Thomas, 1998a: An enhanced hail detection algorithm for the WSR-88D. Wea. Forecasting, 13, 286-303, CrossRef.

, E. D. Mitchell, J. T. Johnson, and K. W. Thomas, 1998b: Evaluating the performance of WSR88D severe storm detection algorithms. Wea. Forecasting, 13, 513-518, CrossRef. 